\title{
Ethnic Politics and the Survival of Minorities' Demands in Sri Lanka: A Historical Review of the Political Advocacy Process of Kalmunai Administrative District Demand
}

\author{
Mohammad Agus Yusoff
}

\author{
School of History, Politics and Strategic Studies, Faculty of Social Sciences \& Humanities \\ Universiti Kebangsaan Malaysia, UKM Bangi-43600, Selangor, Malaysia. Email: agus_ukm@yahoo.com
}

\begin{abstract}
Athambawa Sarjoon
School of History, Politics and Strategic Studies, Faculty of Social Sciences \& Humanities, Universiti Kebangsaan Malaysia UKM Bangi-43600, Selangor, Malaysia \& Department of Political Science, University of Peradeniya, Peradeniya-20400, Sri Lanka

Email: sarjoona@gmail.com
\end{abstract}

Doi:10.5901/ajis.2016.v5n3p61

\begin{abstract}
In Sri Lanka's ethnic politics, the Kalmunai administrative district demand has become the forefront issue in the past few decades. This demand advocates the establishment of a new administrative district-an intermediate decentralized administrative institution connecting the central government and local public in terms of public service delivery, and economic and regional development-for the coastal belt of the present Amparai district in the eastern province. Though the Kalmunai administrative district demand has become a popular concern of the Sri Lanka's ethnic politics in the new millennium and was highly advocated by the political and civil forces among the Muslims of the area, the demand faced ups and downs in its politicization and advocacy process that ultimately challenge the possibilities of establishing the proposed administrative district up till this day. This study attempted to evaluate the history of the politicization and advocacy of the Kalmunai administrative district demand extensively. The finding reveals that although the Kalmunai administrative district demand emerged on rational ground, in due cause, it became over ethnicized and brought more communal criticisms and oppositions that challenged the political advocacy and the success of the demand to a certain extent. Further, the political advocacy of the demand was also on and off in nature and the major advocating party has failed to make the opportunities successful. This study highlights the importance of a continued and collective political advocacy for on rational ground with the purpose of making the Kalmunai administrative district demand a public issue and to transform it as an "input" to the political system for the policy-making process.
\end{abstract}

Keywords: Sri Lanka; ethnic politics; Kalmunai administrative district; political advocacy; SLMC

\section{Introduction}

The strength of civic and political forces and their continued advocacy determines the success of the fulfilment of any political demand. Advocacy is the attempt to influence public policy and practice or any other decisions of an institutional elite. Advocacy activities may be aimed directly at the decision-makers or they may be seeking to indirectly influence through the shaping of public opinion and voters' intentions, or by disseminating alternative models of policy and practices (Casey 2011). When ethnic factors and political forces intertwine with the demand, the advocacy of a demand will be highly challenged. The advocacy for the demand that calls for the establishment of an administrative district by carving out the coastal bel of the present Amparai district in the "south-eastern region" of Sri Lanka has also been challenged by a number of ethic and political factors and forces with the intensity of ethnic conflict and civil war in Sri Lanka.

The demand calling for the establishment of a Kalmunai administrative district has emerged even before the establishment of the present Amparai district in 1961. The people living in the southern part of the Batticaloa district had been demanding a separate administrative district for their area from 1946 onwards on the basis of administrative convenience, improving public service delivery, and inducing regional development. The functions of an emergency Kachcheri (District Secretariat) in Kalmunai from 1942-1946 highly induced the advocacy of this demand (Ibrahim 2002 \& Sarjoon et al., 2015). However, when Amparai district was formed covering the same area in April 1961, the demand for a separate administrative district for the coastal belt of Amparai district emerged and was advocated by the Tamil-speaking 
communities with the accusation of: (1) domination of Sinhalese and Sinhala language in district administration, (2) violation of constitutional provisions and policies in admitting Tamil language as the official language, (3) discrimination of minority rights on administrative affairs (especially of language rights in the administrative practice and equity in civil service appointments), and (4) marginalization of minorities in development initiatives. All these claims induced them to advocate for a separate administrative district that ensures the promotion and practice of their language in district administration, improvement in public service delivery, induction of progressive development, and enhancement of ethnic and social cohesion in the region (Ibrahim 2002; Jabbar 2010; Mohideen 2013a; Mohideen 2013b; \& Sarjoon et al., 2015;). Nevertheless, the the Kalmunai administrative district demand has been politically contested, but has gained political importance in the last 15 years. It was advocated mainly by the Muslims of the region, but the establishment of the proposed Kalmunai district has continued to be sidetracked by the government authorities up to today and yet to be studied academically. On the other hand, the Kalmunai administrative district demand received huge criticisms and oppositions from other ethnic groups and parties on communal grounds. To a certain extent, the ethnicized nature of political advocacy and the communalized oppositions to the demand have imposed huge challenges to the fulfillment of the demand. Similarly, there have been ups and downs in the advocacy of the demand in its 30-year politicization process.

Based on the above backdrop, this study attempted to critically analyze the impacts of ethnic politics in the politicization and advocacy process of the Kalmunai administrative district demand. The major objective of this paper was to review the nature of the politicization process of the Kalmunai administrative district demand, as well as the challenges it faced in its three decades of political survival in Sri Lanka's ethnic politics.

\section{Materials and Methods}

This paper is one of the outcomes of a 3-year research project that extensively studied the Kalmunai administrative district demand. It adopted the descriptive and interpretive methodologies for assessing the ethnicized nature of political advocacy of the Kalmunai administrative district demand and used qualitative methods such as semi-structured in-depth interviews, focus group discussions and participant observation for primary data collection. About 45 informants were chosen from different categories (such as national and local politicians, academics, journalists, and civil activists) as interviewees. Three focus groups discussions were conducted among the three major ethnic groups living in the proposed district-Muslims, Tamils, and Sinhalese. Also, the primary data were collected from participant observation through the field visits to District Secretariat (Amparai), and Divisional Secretariats in the research area. Academic journal articles, books, research publications, government reports, newspaper articles were the major secondary sources used in this study. The primary and the secondary data were analyzed and interpreted based on the events and administrative issues pertaining to this study and were later presented as direct quotations, summaries of interviews and opinions, through descriptive and interpretive manners. The interpretive research helped achieve understanding of the actions of people in social circumstances and situations.

\section{The Kalmunai Administrative District Demand: A Brief Background}

The people living along the coastal belt of the present Amparai district have been demanding for a separate administrative district covering the coastal Divisional Secretariat (DS) divisions' areas as a mechanism to facilitate the functions of the public administration, as well as the development administration. This demand has been prevailing at societal and political levels over the last fifty years. Initially, the major areas of the present Amparai district were part of the Batticaloa administrative district and referred to as the "Batticaloa Southern Region." This region held a concentration of Tamil-speaking Muslims and Tamils including a small portion of Sinhalese before it was demarcated to form the Amparai district in 1961. Though the formation of Amparai district was welcomed by the Tamil-speaking people of the district, the positioning of its secretariat buildings in the Sinhalese area was mainly criticized by them. Furthermore, the naming of the district also received criticisms and opposition from the Tamil-speakers. As the majority of the district population consisted of Tamil-speakers and predominantly lived in the coastal area, the Tamil-speaking communities, namely the Tamils and Muslims, as well as the politicians of the area, demanded that the government should transfer the District Secretariat to one of the towns in the coastal area or form a separate administrative district covering the coastal areas for the sake of the Tamil-speakers (Ibrahim 2002 \& Sarjoon et al., 2015).

The Kalmunai administrative district demand urges the central government that the three coastal electorates of the present Amparai district, particularly Sammanthurai, Kalmunai, and Puttuvil, be declared as a separate administrative 
district. The proposed new administrative district covers an area of $1867.7 \mathrm{sq} . \mathrm{km}$, which is about $40 \%$ of the existing Amparai district's total land (Ibrahim 2002; Jabbar 2010:83 \& Mohideen 2013b:51). The proposed district has a population of 409,260 , according to the 2012 census, which is equivalent to $63 \%$ of the total population of the present Amparai district. Among them, the Muslims constitute $68.60 \%$, Tamils $27.40 \%$, while the Sinhalese constitute $3.5 \%$. The proposed district has 14 divisional administrative units (DSs) and 343 Grama Niladari (GN) divisions (Department of Census and Statistics 2014).

It was found that the establishment of the Kalmunai administrative district has been justified as: (1) a relief to the issues facing by the people of the coastal belt in accessing and receiving services from the Amparai district secretariat and other government departments due to their location, (2) to remove linguistic barriers in district administration due to the domination of Sinhala language, (3) a relief to the Tamil-speakers for the violation of official language act and policy, (4) an institutional mechanism for socio-economic and regional development of the region that was severely affected by the civil war and natural disasters, (5) to facilitate the public in district administration because the existing administrative district is big enough (4 $4^{\text {th }}$ biggest) and the Secretariat is also located far from the Tamil-speakers' settlements, and (6) to strengthen the administrative machinery for development administration based on Moragoda commission's (1978) recommendation (Ibrahim 2002; Noorul Haqu 2002; Jabbar 2010; \& Yusoff et al., 2016).

\section{Nature and Trends of Political Advocacy for the Kalmunai Administrative District: Major Findings}

Initially, the Kalmunai administrative district demand was highly supported and advocated by the Tamil-speaking communities-both the Tamils and the Muslims of the region. However, later on, especially after the escalation of ethnic conflict and civil war in the beginning of the 1980s, the demand was mostly favored by the Muslims and criticized by the Tamils and the Sinhalese. After the 1980s, only the Muslim politicians, organizations, and parties, particularly the Sri Lanka Muslims Congress (SLMC), advocated the establishment of the proposed Kalmunai administrative district. In the recent past, especially after the demise of the SLMC founder leader, M.H.M.Ashraff in 2000, the demand was highly articulated by the SLMC leaders and put forward in its politics of bargaining with the major political parties, which brought not only political popularity and recognition at the national politics, but also more communal criticism and oppositions to the demand. The following sub-sections analyses the nature and the changing dynamics of the political advocacy process of the Kalmunai administrative district demand and the communal oppositions and criticisms it received.

\subsection{Initial Stage of Advocacy (1960s-1970s)—weak and unorganized}

From the establishment of the Amparai district in April 1961, Tamil-speaking people of the district collectively claimed for the transfer of the Amparai District Secretariat (also known as Kachcheri) to one of the towns located along the coastal area, especially to Kalmunai or Akkaraippatthu. It was found that in 1964, Dr.E.M.V.Naganathan, the parliamentarian from the Federal Party (FP), claimed the transfer of Amparai Kachcheri to Akkaraippatthu, a town along the coastal belt of the district. However, due to the lack of support from Muslim representatives and the agitations from the Sinhalese, Naganathan's claim failed (Jabbar 2002). During the mid-1970s, Muslim political activists under M.I.M.Mohideen, who founded the Muslim United Liberation Front (MULF) that advocated for the Muslims' autonomy right and an autonomous political unit in the north-eastern region, also claimed the establishment of a separate Kachcheri in Kalmunai or a separate district for the coastal area of the Amparai district (Mohideen, Personal communication, 9 August, 2014). When the MULF made electoral alliance with the Tamil United Liberation Front (TULF) during 1977 general election, the TULF leaders also accepted the concept of the coastal Kachcheri and Kalmunai administrative district (Ibrahim 2002:6 \& Mohideen, Ibid). However, the demand was not clearly conceptualized in paper format. In 1978, the Moragoda Commission, which was formed to study and recommend reforms in the administrative machinery by the United National Party (UNP) government, recommended the establishment of the new districts of Gampaha, Mullaitivu, Kilinochchi, and Kalmunai, in line with the government initiative of administrative decentralization and to support the development administration process (Noorul Haqu 2002:19; Jabbar 2002:7, Parliament Secretariat 2014a:864-865 \& Hasan Ali, Personal communication, 8 August, 2014). But, government formed the Gampaha and Mullaitivu districts in 1978, and Kilinochchi in 1984 but delayed to form the proposed Kalmunai administrative district.

\subsection{Intensity of Ethnic Conflict and Civil War and the Advocacy of the Kalmunai Administrative District (1980s-1990s)}

Since the 1980s, the Kalmunai administrative district demand came to the forefront of national politics. At that time, the 
entire district administration in Amparai was dominated by the Sinhalese administrators and Sinhala language. Furthermore, the successive central governments attempted to appoint Sinhala administrators to the divisional administrative divisions (AGA divisions) in Tamil-speakers predominated areas. In the beginning of 1980s, out of the 12 AGA divisions, only 4 divisions were headed by a Tamil-speaking AGA within the district (Mohideen 2013b). On the other hand, government purposively started to shift all major offices handling district-based administrative functions that were located along the coastal belt, especially from Kalmunai town to Amparai town, which caused a number of issues and difficulties to the people of coastal belt when it came to accessing services from those offices. Considering all these issues, the All Ceylon Muslim League, an organization that had claimed to change the name of the Amparai district to "Kalmunai" on the grounds of the Muslim majority in the district's population, passed a resolution calling for the establishment of a "Kalmunai" administrative district by merging Kalmunai, Sammanthurai, and Pottuvil electorate areas, in its annual meeting held in November 1981. The justification was on the linguistic basis that though the majority of the Amparai district's population are Tamil-speakers, all administrative functions were communicated in the Sinhala language and the administration was dominated by the Sinhalese (Noorul Haqu 2002:19 \& Uthayan 1981:1). Following this resolution, the Muslim civil society organizations within the region were also actively engaged in discussing the administrative issues faced by the Tamil-speakers due to the Sinhalese domination in the district administration and other related factors. A one-day seminar was organized in Kalmunai Zahira College in 1984 to discuss the matter in detail. A number of civil society members, including academicians, lawyers, religious leaders, trustees, community leaders, along with political representatives of the region, participated in this seminar. They unanimously passed a resolution requesting government authorities to make attempts to ensure the formation of the Kalmunai district (Athambawa 2011 \& Noorul Haqu, Personal communication, 3 August, 2014).

Due to the high pressure from civil society organizations on this matter, the UNP government also made necessary preparations to form the Kalmunai district in the mid-1980s. It was reported in a pro-government newspaper in 1985 that the new Kalmunai administrative district would be declared in July and Mr.Makbool, the AGA of Mannar district would take charge as the Kalmunai District Secretary (Noorul Haqu 2002:19). Muslim ministers namely, M.H.Mohamed and A.C.S.Hameed also promised that the government would form the Kalmunai district. However, due to the ethnic conflict and ethnic politics, after admitting the opposition of the MPs representing the eastern province in the UNP, the government abandoned its plan. However, the Sri Lanka Muslim Congress (SLMC), emerged as a Muslim political party in 1986 continued to moderately advocate the demand in many occasions, especially during elections.

With the intensity of civil war from the middle of 1985 and number of serious incidents that were staged targeting the Muslims in the coastal area of the Amparai district, the Muslim community was compelled to reconsider their administrative district claim again. In 1994, Kalmunai Pradesiya Sabah (a local government body) passed a resolution in favor of the demand. The Chairman of Kalmunai Pradesiya Sabah, I.A.Habeeb Mohamed, proposed the resolution requesting the government to form the Kalmunai administrative district covering the local government bodies of the coastal belt of the Amparai district under the capital of Kalmunai. The resolution was critically discussed by all parties representing the council and it was then unanimously accepted by the council (Noorul Haqu 2002:22). Following this resolution, however, no meaningful initiatives were taken by the Muslim political and civil forces to materialize the demand. Even though the founder leader of the SLMC, M.H.M.Ashraff, was representing the people of this region in parliament from 1989 to 2000 and made a number of speeches in parliament touching on the issues, including the administrative issues in the district such as the Sinhalization of the district administration, domination of Sinhalese in the district secretariat, transport and communicative difficulties, discriminative actions in the matter of land allocation, land settlement programs, and land delimitation, no speech was recorded by Ashraff directly requesting the parliament and government authorities to consider the Kalmunai administrative district demand and forming it. However, throughout his career in parliament, Ashraff had been advocating a political autonomous unit for the north-eastern Muslims in the negotiated settlement to the ethnic conflict in Sri Lanka (See: Hakeem (n.d): vol. i-vi). It is worth noting that since the SLMC had been strongly advocating the establishment of a Muslim-majority provincial council (a political autonomous unit) in the north-eastern region in during 1980s and 1990s, the advocacy for Kalmunai administrative district was moderate or rather silent.

The SLMC, under its founder leader, Ashraff, was very much influential in both the Muslim and national politics in Sri Lanka from 1994 to 2000. As the sole and national leader of the SLMC, Ashraff was extremely influential in the People's Alliance (PA) cabinet with the portfolio of Rehabilitation, Reconstitution, and Ports and Shipping. He was instrumental in politicizing and internationalizing the issues faced by the Muslim community in the course of the country's ethnic conflict and civil war. When the PA launched a negotiation process to find political solution through constitutional amendment, Ashraff also put forward a proposal on establishing a Muslim-majority autonomous unit for the shake of the 
north-eastern Muslims and convinced the parties in the negotiation table to be accepted it. His proposal for Muslim autonomous political unit was incorporated in the new draft constitution, but no meaningful initiatives were taken by him on the formation of Kalmunai administrative district in spite of his powerful influence within the cabinet. However, he did list out the establishment of the proposed district as a subject of the demand in the SLMC's proposal submitted to the PA government in 1995 (Ameerdeen 2006:230). Only at the last stage of his active politics, just before the 2000 general election more specifically, did Ashraff put the demand as a condition to continue his party's support with the coalition government. Unfortunately, Ashraff was met with his sudden demise in September 2000, just a few days before the general election.

\subsection{Serious Advocacy for Kalmunai Administrative District (2000 Onwards)}

The demand calling for the formation of Kalmunai administrative district was put forward on political bargaining table by the SLMC for the first time in an organized way during the 2000 general election. The sudden demise of SLMC'S founder leader, M.H.M.Ashraff on $16^{\text {th }}$ September 2000 in a helicopter crash upraised SLMC's popularity in the electoral politics. In the 2000 parliamentary elections, the PA won 100 out of 225 parliamentary seats, but fell short by 13 to form a simple majority in the House. While the Janatha Vimukthi Peramuna (JVP) with its 10 seats refused to play ball, the Eelam People's Democratic Party (EPDP), with its strong views against the Liberation Tigers of Tamil Eelam (LTTE), was the first to offer itself with its 5 members to the PA. The SLMC, which had just a few days earlier lost its founder, played a little harder to get under its new leader, Rauff Hakeem. The party had 11 seats and Hakeem was suddenly the kingmaker. Finally, when Hakeem relented in favor of the PA, he had extracted what seemed like an awful lot: two cabinet berths, three deputy ministerial posts, and a raft of other appointments in the government (Subramanian 2001).

With Hakeem on its side, the government had 116 seats, which gave it a majority of 4 in parliament. However, there was a hex on the partnership from the beginning. For all the concessions he acquired from Chandrika Kumaratunga, Hakeem was still angered over the alleged election irregularities by a senior member of the PA in his electoral district of Kandy. On the other hand, within days of the formation of the new government, Hakeem put it on a 100-day notice that requested the government fulfill some demands within a given timeframe. Among the demands, the setting up of an independent election commission, as well as form commissions for the police, media, and the judiciary; the upgrading of the Kalmunai Urban Council into Municipal Council; and the formation of a new administrative district by carving out the three electorates of the coastal area of the present Amparai district, namely Sammanthurai, Kalmunai, and Pottuvil were prominent (Deshavimala 2001). Later, the SLMC leaders requested the party parliamentarians to strictly adhere to the party's decision on the 100-day notice.

President Kumaratunga attempted to form the Kalmunai administrative district together with the establishment of the Mahiyangana one, but her attempt was very much criticized by many parties within and outside the government. There were oppositions among certain government ministers, especially Minister A.H.M.Fousi who demonstrated a strong opposition and requested the President to reconsider her decision. On the other hand, Tamil political parties and civil organizations in the Amparai coastal area expressed their strong opposition through reports and agitations. The JVP, formerly a radical force, but later entered parliamentary politics, went on the streets with the huge support of the Sinhalese public from the Amparai town and opposed the government's decision to establish the Kalmunai administrative district. The JVP used its one and only Muslim MP, Anjaan Ummah, for this purpose (Ibrahim 2002:1). Due to high pressure and stiff resistance within the cabinet and from political parties and civil forces, the PA government abandoned the initiatives to establish the new district (Satyapalan 2001).

The 100-day deadline of SLMC's co-leader, Hakeem died a natural death. However, throughout the passing of 100 days, Hakeem kept quiet on his threat, but as the deadline drew near and the media constantly played it up, Hakeem stated in parliament that he would spring surprises. The government failed to be aware that Hakeem was serious about his deadline. Instead, President Kumaratunga announced the upgrading of the Kalmunai town council alone to a municipality (Deshavimala 2001). In June 2001, Hakeem expressed his and his party's concern towards the 100-day demand. In mid-June, in a press conference, after a long meeting with President Kumaratunga, Hakeem went public with his list of complaints against the PA government, reporting that "It is not just one issue; it is a chain of events that has made the SLMC's support to the government difficult to justify to its supporters" (Subramanian 2001). It was at the same press conference where Hakeem had warned Kumaratunga not to "mess" with the SLMC. Three days later, on the night of June 19, Kumaratunga sacked him from the cabinet, perhaps based on a gamble that this would isolate him within an already divided SLMC and that Ferial Ashraff, the other co-leader of the SLMC, would automatically take over the party and prove a more cooperative partner for the PA than Hakeem. However, as Subramanian (2001) correctly stated, it was 
a poor political judgment. The party stood by Hakeem, with all those in ministerial and other positions, including Ferial Ashraff, submitting their resignations the very next day.

It is worth noting here that Hakeem's decision to withdraw the support for the PA government caused the first serious split within the party that also challenged the advocacy and the feasibility of establishing the Kalmunai administrative district. While Hakeem met Kumaratunga for talks, the SLMC's high command or the supreme council discussed this issue. Supporters of Hakeem raised the 100-day deadline issue to seek support for Hakeem. Supporters of Ferial Ashraff protested, as it was a personal decision of Hakeem's and the party had nothing to discuss on that matter. The argument ended with violence between the two groups (Deshavimala 2001). Even though the SLMC was divided on the above issue, no statement was made by the other co-leader, Ferial Ashraff. She too had said that she stood by Hakeem's decision, but tensions within the SLMC continued. Later, when Hakeem crossed over to the opposition benches in the Parliament that afternoon, only six other MPs of the party accompanied him, while Ferial Ashraff and three others continued to sit on the government benches. The soft-spoken Ferial Ashraff then said that there was no reason for her to topple the PA government at this stage (Subramanian 2001). Ferial Ashraff's continuous support for the government clearly demonstrated that a strong split would soon happen within the party. With all these controversies, President Kumaratunga dissolved the parliament on 10 th October 2001, immediately after one year and called for a general election on $5^{\text {th }}$ December 2001.

When the United National Front (UNF) formed a coalition government with the support of the SLMC after the December 2001 general election, the SLMC once again put forward its Kalmunai administrative district demand before the UNF government. In 2003, the UNF government prepared a cabinet paper on establishing two new administrative districts, one for Kalmunai and the other for Kuliyapiddiya, but due to the failure to build consensus between the SLMC Leader, Hakeem and the SLMC parliamentarian, A.L.M.Athaullah from Akkaraippatthu, on the matter of naming the proposed district and placing its secretariat, the attempt was once again abandoned. Athaullah claimed that "Akkaraippattu" should be named the capital of the new district instead of Kalmunai and the district secretariat should also be established in "Akkaraippatthu." However, opposing this claim, the SLMC leaders held a strong stance in naming "Kalmunai" as the capital of the district with the justification that there was an emergency Kachcheri in Kalmunai and the founder leader of the SLMC, Ashraff, had also proposed it. Hakeem brought up this matter in a meeting at Maruthamunai during the 2005 presidential election campaign, that when he had prolonged the matter for some time and re-negotiated it with the people of Kalmunai, Athaullah had turned it down again and prevented the tabling of a cabinet paper (Skynetbit.com 2005). Therefore, turmoil with the Kalmunai administrative district matter increased. Since President Kumaratunga dissolved the parliament in February 2004, two years after the formation of the UNF government, nothing could be materialized on this matter.

During the 2005 Presidential election, the SLMC made a coalition with the UNP, therefore supporting the UNP presidential candidate, Ranil Wickremesinghe, on the assumption that the UNP and its leaders would fulfill the SLMC's long-term Kalmunai administrative district demand, together with the demands for a Muslim-majority autonomy unit. The UNP election manifesto incorporated the subject on the establishment of the Kalmunai administrative district as one of the priority worklist, but at the election, the UNP leader failed to succeed President Kumaratunga and Mahinda Rajapaksa from Kumaratunga's party was therefore elected as the President of Sri Lanka. Since then, Rajapaksa's government made its utmost attempt to defeat the separatist claims of the Liberation Tigers of Tamil Eelam (LTTE) through military power and there was no room for the SLMC or Muslims to voice for a separate administrative district. Thereafter, the demand was once again hand-offed by the Muslim leaders.

\subsection{Post-Civil War Advocacy: Unsettled Promises and Huge Criticisms and Oppositions}

With the end of civil war in May 2009, the SLMC once again started to advocate the establishment of Kalmunai administrative district in its electoral politics more seriously, together with its long-term Muslim autonomy demand. During and after the 2010 general election, SLMC leaders put it forward as one of their priority demands and a major condition to form coalition with the major political parties. Although the demand was accommodated by the United People Freedom Alliance (UPFA), in its coalition agreement, no initiative was made to establish the proposed district. When SLMC leaders intensified their advocacy to the demand, however, it received huge criticisms and oppositions among the majority Sinhalese and Tamils, as well as by the parties representing them. However, SLMC leaders repeatedly sought the UPFA government's firm assurance on this particular demand in return for their support.

From 2012 onwards, there were harsh voices and violent incidents against Muslims in many parts of Sri Lanka. The forces against Muslims once again took anti-Muslim sentiments as a means to survive in ethnic and electoral politics. 
Through anti-Muslims propaganda, they mobilized religious forces and acted violently against Muslims and criticized the following of Islamic fundamentals. A number of mosques were attacked and business places and other important ownership belonging to Muslims were also targeted. A series of agitations were staged against the issuing of Halal certificates for food items, slaughtering animals for human consumption and religious rituals, and the practicing of a separate judicial system for Muslims (Farook 2014; Senaratne 2014; Sarjoon et al., 2016 \& Yusoff and Sarjoon 2016). These anti-Muslim violence agitations intensified the fear of existence among the Muslims and they insisted their political leaders leave the government. Therefore, from 2012 onwards, the SLMC and the Muslims of Amparai district seriously demanded the government declare the Kalmunai administrative district, along with the call to protect their religious places and safeguard them from the violence of anti-Muslims forces.

Along with anti-Muslim violence, the election held for the Eastern Provincial council in September 2012 produced no party majority that could form the provincial government. The SLMC contested the election alone, with the anti-Muslim sentiments and violence staged by the extreme Buddhist forces as a capital of its election propaganda. It received 7 seats that became crucially important in forming a provincial government by any party. Both the Tamils National Alliance (TNA) that received 11 seats and the UPFA that received 7 seats called for the SLMC's support to form a provincial government. The TNA was openly reported to concede the Chief Minister's (CM) post to the SLMC (Colombo Telegraph 2012 \& Jeyaraj 2012a). Based on this context, after deeply discussing several matters with its high command, the SLMC leaders decided to support the UPFA amidst huge criticisms from different sites, considering the number of factors, but put forward several demands or conditions (See: Jeyaraj 2012b). The top most demand of the SLMC was to carve out a new administrative district in Amparai, but when the UPFA formed the provincial government, nothing, except two ministerial and other key posts in the provincial government was gained by the SLMC. The SLMC's support to form a UPFA-led government in the eastern province was very much criticized by the Muslims and the Tamil parties, but SLMC continued to believe the promises made by the UPFA leaders with regards to the establishment of the Kalmunai administrative district, together with the assurance of Muslims' security in the country. The SLMC leaders claimed that they signed an agreement on this regard (Hasan Ali 2014, Personal Communication, 8 August, 2014 \& Parliament Secretariat 2014b:3044-3045). However, the UPFA leaders later denied it. In fact, the government succeeded in gaining support of the SLMC in many crucial occasions without any cost and continued to neglect the promises made with the SLMC, particularly with regards to the establishment of the Kalmunai administrative district.

The continuous negligence of the promises made by the UPFA government on the Kalmunai administrative district matter, along with the continuation of anti-Muslim violence around the country, frustrated the Muslim community. Therefore, voices were raised against Muslim political leaders. In February 2013, a resolution was unanimously adopted at a meeting held in Nintavur, in which the Amparai district SLMC representatives gathered. The resolution claimed that the government should announce the formation of a Kalmunai administrative district within one month. The resolution further demanded that the party leaders should willingly or unwillingly announce that the SLMC ministers would resign from their portfolios if the government failed to meet the demands within the period of one month (The Island 2013). SLMC sources reported that the SLMC will not have second thoughts of quitting the government if it failed to establish the Kalmunai district (Rizwie 2013).

The year 2014 was also an important year in the discourse and advocacy of the Kalmunai administrative district demand. The SLMC leaders continued to urge the UPFA government to fulfill the promises made with them, including the formation of Kalmunai district. However, government went on sidetracking the SLMC's request and planned to attract the support of the SLMC representatives by offering the Chief Minister (CM) post in the Eastern Provincial council. The SLMC leaders were not ready to lose the Kalmunai district for the two-and-a-half-year CM post. The Deputy Director of the SLMC's International Affairs Wing and the SLMC's group leader in the eastern provincial council, A.M.Jameel claimed that the proposed new Kalmunai administrative district should be carved out before the presidential election that was expected to be held in 2015 and the SLMC would not accept the CM post of the Eastern Provincial council before creating the Kalmunai administrative district, as it was demanded during the eastern provincial council election and already agreed upon by the ruling party after the election (Gurunathan 2014).

When the SLMC repeated its demands for a Muslim-majority Kalmunai administrative district during the 2015 budget discussion started on $3^{\text {rd }}$ November 2014, it received huge criticisms from different parties in parliament, including the government's side and the major opposition party, the UNP. The UNP Colombo district parliamentarian, Wijeyadasa Rajapakshe, reported that "the SLMC's demand for a Muslim-majority administrative unit in the eastern province is very much similar to the LTTE's demand for a separate state in the northern and eastern provinces of Sri Lanka. This is a dangerous trend in politics. All of us must oppose the SLMC's move. The government has the wherewithal to act against such projects" (Inthrajith 2014). Rajapakshe further pointed out that the SLMC's call for a separate administrative unit was 
equal to the separatist demands by Tamil leaders like Amirthalingam and Chelvanayagam. Their actions paved the way for Tamil youths to take up arms against the government. The SLMC tried to do the same. The separatist project launched by the SLMC should be strongly opposed by other political parties (Tamil Guardian 2014). The UPFA's Prime Minister, D.M.Jayarathne also endorsed the views expressed by the opposition parliamentarian Rajapakshe. The Prime Minister, who thanked the UNP leaders for highlighting the issue, revealed that the government too would not approve of moves to divide the country based on ethnic lines (Parliament Secretariat 2014b). Many directed accusations at the SLMC, stating that it was an attempt to create a Muslim Eelam (State).

In response to the criticism posted by many sides, including the government, the SLMC representatives made visionary statements inside and outside the parliament. Hasan Ali, the secretary general of the SLMC, revealed that "the SLMC had signed a memorandum of understanding with the government, as the government had agreed to allow a separate administrative district in Amparai during the 2012 eastern provincial council election. We are not asking for a separate province, only an administrative district like the other twenty-five. Before 1961, Amparai was a part of the Batticaloa district. The electorates of Sammanthurai, Kalmunai, and Pottuvil that formed the southern part of the Batticaloa district were earlier known as the Kalmunai region along with Amparai" (Parliament Secretariat 2014b:30413046 \& Seity.com 2014).

There were supports from the Muslim civil society and the political forces to the SLMC's Kalmunai administrative district demand during 2014. The leader of the Tamil-Muslim Alliance, Asad Sally, added that this was not a new demand, but the Muslims in the area had been asking for a separate administrative district for a long time. During President Kumarathunga's regime, Ashraff negotiated and got a DRO's office to Kalmunai, but now the government has taken it back to Amparai. The present government and even the UNP government had promised to make necessary administrative arrangements, but they have failed to do so (Karunarathne 2014). Speaking to the newspapers, the president of the Muslim Council of Sri Lanka, N.M.Ameen, added that the proposal was not particularly for the Muslims, but for the Tamil-speaking people in the area (Karunarathne 2014). Ameen further condemned reiterating the view of the SLMC that in the Amparai GA's office (Kachcheri), the entire administration runs in Sinhala and the Tamil-speaking majority in the area face communication barriers. There are Sinhala AGA divisions in Vavuniya for Sinhala-speaking minorities in those areas and the Muslims would also welcome such arrangements for Tamil-speakers in Amparai district for their administrative convenience (Karunarathne 2014).

In response to the criticisms expressed to the Kalmunai administrative district demand, M.H.M.Harees, a parliamentarian representing the Amparai district from the SLMC, made a strong statement in parliament that "in truth, this is not a proposal that was put forward by the Muslim Congress. The Moragoda Commission, appointed in 1978, by the then President J.R.Jayewardene made this recommendation. Two years ago, during discussions to establish the eastern provincial council, five senior Ministers in the government promised that they would provide the Kalmunai administrative district" (Parliament Secretariat 2014a:864-867 \& News First 2014). At the end of the budget debate, however, W.D.J.Senaviratne, the Minister of Public Administration and Home Affairs, stated that "practically, there are inconveniences that are being faced by Muslims living in areas of Amparai. This is because they have to come to Amparai to conduct their affairs. I too am of the opinion that there should be an administrative decision here to enable them to conduct affairs in the Tamil language" (Parliament Secretariat 2014a \& News First 2014).

However, the calling for the 2015 Presidential election made the demand the main themes of the election campaigns. It also made the demand more politicized and communalized. President Rajapaksa wanted to remain in power for the third term too. His leadership and party were unfortunately criticized by the Muslim community due to their inefficiency in controlling the anti-Muslim incidents staged by the radical Buddhist forces from 2009 onwards. However, Rajapaksa's side also wished to acquire the support of the SLMC in order to gain support of the Muslim community. The SLMC leaders were very firm with their demands, especially with the Kalmunai administrative district one. There were a number of meetings with the SLMC leaders in this regard, but after weeks of dilly-dallying, the SLMC broke its relation with the government and announced its support to common Presidential candidate, Maithripala Sirisena, even though the candidate or the alliance did not give any assurance regarding the establishment of the proposed Kalmunai administrative district.

When the SLMC left the UPFA government just ten days before the presidential election and supported the common opposition candidate, the UPFA government used this opportunity to miss-conceptualize and propagate the Kalmunai administrative district demand equality with the LTTE's demand for a separate state in the north-east. It was the theme of the electoral campaigns of the UPFA alliance and the Sinhalese-Buddhist forces against Muslims. They not only miss-conceptualized the proposed administrative district into a demand for a political autonomous unit, but also communalized the demand, as it is a political autonomous unit for Muslims in the eastern province. Following statement 
made by the general secretary of the SLFP and the then Petroleum Industries Minister of the ruling UPFA, Anura Priyadarshana Yapa, clearly indicated that the UPFA leaders were misinterpreting the Kalmunai administrative district demand.

The SLMC leaders left the government, as the President did not agree to establish a separate administrative district for Muslims. The SLMC was engaged in an unsuccessful attempt to realize one more goal in the international conspiracy to make Sri Lanka an unstable country. We have already granted equal rights and opportunities to all in every part of the country while ending terrorism that had affected the entire nation for over three decades. In such a situation, establishing a separate administrative district for Muslims can cause damage to peace and unity in the motherland. The unjust demand of the SLMC could be a threat to the unity of Sri Lanka. Their demand is extremely similar to the LTTE'S demand for Eelam (Think Worth 2015).

As viewed above, even though the SLMC and the Muslims of the coastal belt of Amparai district have been highly advocating and urging the government to establish a separate administrative district in the post-war context, the demand has continuously been criticized and sidetracked by the political forces in the government and the parties agreed during coalition politics. However, this study has identified that there were three crucial occasions that made opportunities for the SLMC leaders to make the demand successful in the past. However, the SLMC leaders have failed to do so due to many factors, including the internal crisis of the party. Following are those three occasions:

\subsubsection{During Ashraff Era (1988-1991)}

The founder-leader of the SLMC, M.H.M.Ashraff, played a vital role in politicizing issues and demands of Muslims in Sri Lanka at national, as well as international levels. He played an active role in national politics from 1989 to 2000, initially as an opposition member of the parliament (1989-1994) and then as an influential partner of the coalition government of the PA (1994-2000). However, he declared the SLMC, a social-welfare organization formed in 1981, as a political party in 1986 and gained political popularity when his party became the third major political forces in the country after the provincial council elections held in November 1988, just one month before the presidential election. During the 1988 presidential election, there had been voices against the policies and governance of the UNP government and for a political change in the country. Therefore, the UNP presidential candidate and the then Prime Minister, Ranasinghe Premadasa, called for the electoral support of the SLMC and Ashraff. However, Ashraff extended the support of his party with the condition to reduce the cut-off vote (from $12.5 \%$ to $5 \%$ ) in the proportional representation system that conditioned a party or a group to be qualified for the selection of representation from a district in the parliament election. Since Premadasa accepted the condition and fulfilled it through the Fifteenth Amendment to the constitution certified on 17 December 1988 just two days before the election, the SLMC leaders urged the Muslims to vote for the presidential candidate of the UNP. During that election, Premadasa won only with the margin of $50.43 \%$ of valid votes. In all Muslimmajority electorates in the north-eastern region, the major vote bank of the SLMC, Premadasa received more than $50 \%$ of votes (Department of Elections 1988).

During Ashraff's first tenure in parliament (1989-1994), he unofficially supported the initiatives of the government and President Premadasa although the UNP government had two-thirds majority in the parliament. In fact, Ashraff's support was crucial importance for the President at that time. Through his unofficial support, not only did Ashraff bring benefits to his community, he also strengthened the hands of President Premadasa. Until the impeachment motion was put forward against President Premadasa in parliament in August 1991, Premadasa's government enjoyed a two-thirds majority in the parliament. Premadasa was compelled to beg the support of the SLMC during this period and he and his cabinet were ready to fulfill any kinds of request or demands from Ashraff. During this period, Ashraff could have been able to put forward this Kalmunai administrative district demand and pushed the President Premadasa to form it. However, no records prevailed that Ashraff did so. Since the Premadasa's government had two-thirds majority in the parliament, which is mandatory for any changes or alteration in the constitution, Ashraff failed to materialize the Kalmunai administrative district demand. Even though the SLMC leaders and activists proudly claimed that the reduction of district based cut-off vote from $12.5 \%$ to $5 \%$ was made at the request of the SLMC leader, Ashraff failed to materialize the Kalmunai district demand during this period.

\subsubsection{During Rauff Hakeem Era (in 2010)}

There was another matured opportunity for the SLMC leaders to materialize the Kalmunai district demand in 2010. In 
2010, President Mahinda Rajapaksa pleaded the SLMC to secure two-thirds majority in parliament, necessary to pass the Eighteenth Amendment to the constitution that was expected to change the provision to a president, if he/she elected, to serve any number of terms, which was limited to only two six-year terms by the previously provisions. Since President Rajapaksa was expected to continue in power and he lacked with six more members to secure the two-thirds majority to pass the Eighteenth Amendment in parliament, he was ready to give any prize to get the support of the SLMC's members in Parliament for this. There were many criticisms to the move of this constitutional amendment as an extremely controversial amendment with deep political implications, but at the end, the SLMC supported this constitutional amendment without getting any cabinet or ministerial posts as quid pro-quo for this support while being in the opposition wing. Since the SLMC supported this constitutional amendment, they could have used this opportunity to include the Kalmunai district matter as one of the subjects in the Eighteenth Amendment. But, SLMC leaders have failed in this regard.

\subsubsection{During Rauff Hakeem Era (in 2012)}

In 2012, after the eastern provincial council election, the UPFA, headed by the President Mahinda Rajapaksa, wanted to sustain in power in the eastern province to show his political support in the eastern province to the international community. Furthermore, having power control in the eastern province was strategically important for the government to further undermine the autonomous and separatist demands of minorities. Therefore, President Rajapaksa was compelled to beg the support of the SLMC to form the government, since no party gained the majority after the election. There were agitations and worries among the Muslims and the SLMC leaders over continuous negligence by the government towards establishing the Kalmunai administrative district as it promised before. Therefore, the SLMC could have used this opportunity to push the government to declare the Kalmunai administrative district before it extended its support to the UPFA to form the eastern provincial government or convince the UPFA to sign an agreement in this regard. The SLMC leaders failed to do both, but supported the UPFA to form a provincial government.

Although, the SLMC leaders have reported many factors for not to materialized the opportunities to establish the Kalmunai administrative district, including internal party crisis and pressures from the government authorities, however, it shows the weakness or the failure of Muslim politics in the advocacy of the Kalmunai administrative district demand.

\section{Concluding Remarks}

The Tamil-speaking people, particularly the Muslims living along the coastal belt of the present Amparai district in Sri Lanka, have been demanding for the establishment of an administrative district (referred to as the "Kalmunai") for their area (referred to as the "South-Eastern region") as to facilitate them in accessing public services, functions of development administration, and other purposes. The Kalmunai administrative district demand received a number of challenges and oppositions during its long way of advocacy by the Muslim community and the SLMC, the major Muslim political party with high political voter bank in the "South-Eastern region" of Sri Lanka. Although the demand was initially supported and advocated by both Tamils and Muslims under the slogan of Tamil-speaking people, because of intensified ethnic conflict and civil war and their ethnic-based impact, from 1980s onwards, the demand was mostly advocated by the Muslim community and politicians and opposed by the Tamils and later by the Sinhalese and their leaders. The SLMC, the one and only political force advocating the demand for the last three decades finds the establishment of the proposed Kalmunai administrative district as an institutional mechanism not only to reconcile the administrative grievances, but also to safeguard the Muslim community from the ethnic politics and discriminatory policies and programs of the administration of the present Amparai district. This ethnocentric objective induced them to seriously articulate the proposed administrative district as a Muslim-majority district, but in turn, it brought more communal criticisms and oppositions to the demand from other ethnic groups and major political parties.

On the other hand, the advocacy for the Kalmunai administrative district demand was also on and off in nature. The history of SLMC politics revealed that only during elections the SLMC leaders and their supporters take the demand as a political weapon to make coalition with the major political parties or show their political bargaining power in the national politics and urge the parties and government authorities to establish the proposed Kalmunai administrative district in due time. During electoral campaigns, the advocacy for the demand would be on its peak. However, when the SLMC allied with the ruling party, their advocacy for the demand would be weak until the end of the regime or up to the next election. It was found that although the demand has gained political importance over the last three decades and was able to be accommodated at least in political agreements and election manifestos, the SLMC leaders have failed to utilize 
the opportunities favoring them to push or convince the government authorities and parties to establish the proposed Kalmunai administrative district, due to internal crisis within the parties and the lack of unity among the Muslim leaders on the subject of the demand.

Therefore, this study suggests that the SLMC leaders should reshape or re-conceptualize the Kalmunai administrative district demand as a rational and public demand acceptable by other ethnic groups and political parties. It was found that over-ethnicization of the Kalmunai administrative district demand by the Muslim political and social actors has also made the demand unsuccessful and highly debatable on communal basis. The success of any political demand highly depends on the rationale of the demand and its rational and continued advocacy.

\section{References}

Ameerdeen, V. 2006. Ethnic politics of Muslims in Sri Lanka. Kandy: Center for Minority Studies.

Athambawa, S.H. 2011. En ninaivuth thiraiyil Ashraff (in Tamil). (2nd ed.). Sainthamaruthu: Kalamush-Sharq Publication.

Casey, J. 2011. Understanding advocacy: a primer on the policy-making role of nonprofit organizations. New York: Baruch College, City University of New York.

Colombo Telegraph. 2012. TNA stake the claim to form the eastern provincial administration together with the SLMC and UNP. [Online] Available: $\quad$ https://www.colombotelegraph.com/index.php/tna-stake-the-claim-to-form-the-eastern-provincial-administrationtogether-with-the-slmc-and-unp/ (May 10, 2016).

Department of Census and Statistics. 2014. Census of population and housing-2012 (new) - final report. Colombo: Department of Census and Statistics. [Online] Available: http://www.statistics.gov.Ik/PopHouSat/CPH2012Visualization/htdocs/index.php?use case=indicator\&action=Map\&indld=10 (December 20, 2014).

Department of Elections. 1988. Result of the presidential election 1988. Colombo: Department of Elections. [Online] available: http://52.1.201.50/web/images/pdf/past-presidential-election-results/result-of-presidential-election-1988.pdf (December 20, 2015).

Deshavimala. 2001. Hakeem's new line over his deadline. The Island. 28 January. [Online] Avaiable: http://www.island.Ik/2001/01/28/ defenc02.html (January 1, 2015).

Farook, L. 2014. Sri Lankan Muslims: meticulously planned and executed to military precision. [Online] Available: http://www.latheef farook.com/index.php/srilanka-muslims/1152-killing-of-muslims-in-sri-lanka. (January 4, 2015).

Gurunathan, S. 2014. SLMC repeats demand for administrative district in the east. The Ceylon Today, 13 October. [Online] Available: http://www.ceylontoday.Ik/51-75330-news-detail-slmc-repeats-demand-for-administrative-district-in-the-east.html (November 8, 2014).

Hakeem, R (ed.). (n.d). Ashraff in parliament (Vol.i - Vol.vi). Colombo: Sri Lanka Muslim Congress Publication.

Ibrahim, I.L.M. 2002. Kalmunai coastal district. Sammanthurai: Author's Publication.

Indrajith, S. 2014. Wijeyadasa tears into SLMC demand for separate unit for eastern Muslims: PM endorses UNPer's view. The Island. 4 November. [Online] Available: http://www.island.Ik/index.php?page_cat=article-details\&page=article-etails\&code_title= 113515 November 15, 2014).

Jabbar, M.A. 2002. The importance of Kalmunai coastal district on the process of administrative decentralization. Seminar paper. National seminar on New Trends in Social Sciences. South Eastern University of Sri Lanka, Oluvil. 10-11 April.

Jabbar, M.A. 2010. Creation of new administrative district for Tamil-speaking people in Amparai: a critical analysis. Kalam: Research Journal of Faculty of Arts and Culture, 7, 80-92.

Jeyaraj, D.B.S. 2012a. TNA trying to form eastern administration with UNP support under Muslim chief minister. [Online] Available: http://dbsjeyaraj.com/dbsj/archives/10413 (May 10, 2016).

Jeyaraj, D.B.S. 2012b. Muslim Congress will support UPFA in east but remains officially 'undecided' still. [Online] Available: http://dbsjeyaraj.com/dbsj/archives/10447 (May 10, 2016).

Karunarathne, W. 2014. Muslim congress demand for Muslim majority administrative district in Amparai is not a demand for a 'Muslim Eelam.' [Online] Available: http://dbsjeyaraj.com/dbsj/archives/34783 (January 1, 2015).

Mohideen, M.I.M. 2013a. Sinhalisation of east: a reply to minister Champika Ranawaka. The /sland. [Online] Available: http://www.island. Ik/2007/12/27/features5.html (December 12, 2014).

Mohideen, M.I.M. 2013b. Eastern Muslims must unite politically. Colombo: Al-Ceylan Muslim Documentation Center.

News First. 2014. SLMC's demand for new administrative district taken up for debate in Parliament. News First. 8 November. [Online] Available: $\quad$ http://newsfirst.lk/english/2014/11/sImcs-demand-new-administrative-district-east-taken-debate-parliament/61903 (December 27, 2014).

Noorul Hagu, 2002. M.M.M. Minorities: some observations. Sainthamaruthu: Marutham Kalai Ilakkiya Vattam. 2002.

Parliament Secretariat. 2014a. Parliamentary debates (Hansard) official report. 231(5), 864-867.

Parliament Secretariat. 2014b. Parliamentary debates (Hansard) official report. 231(16), 3041-3046.

Rizwie, R. 2013. 'Give Kalmunai or else!' says SLMC. The Nation Sunday, 17 February. [Online] Available: http://www.nation.Ik/edition/ news-online/item/15899-\%E2\%80\%98give-kalmunai-or-else\%E2\%80\%99-says-slmc.html (June 10, 2014).

Sarjoon, A., Yusoff, M.A., Hussin, N. \& Awang, A. 2015. The demand for an administrative district for the costal belt of Amparai district in Sri Lanka: an assessment of its root causes. Mediterranean Journal of Social Sciences, 6(4S3), 434-443.

Sarjoon, A, Yusoff, M.A \& Hussin, N. 2016. Anti-Muslim sentiments and violence: a major threat to ethnic reconciliation and ethnic 
harmony in post-war Sri Lanka. Religions, 7(10):1-18.

Satyapalan, F.R. 2001. Hakeem group to withdraw support to PA? The Island, 13 June. [Online] Available: http://www.island.|k/ 2001/06/13/news18.html (April 30, 2015).

Seity.com. 2014. If Muslim's grievances are met SLMC will support common candidate. [Online] Available: http://www.seithy.com/breif News.php?newsID=120467\& category=EnglishNews (January 1, 2015).

Senaratne, K. 2014. Politics of Alutgama. Colombo: Ground View. [Online] Available: http://groundviews.org/2014/06/22/the-politics-ofaluthgamal (January 4, 2015).

Skynetbit.com. 2005. Mahanida had no plans for Kalmuani coastal district-Hakeem. [Online] Available: http://skynetbit.blogspot.com/ 2005/10/mhanida-had-no-plans-for-kalmuani.html (July 10, 2014).

Subramanian, N. 2001. Chandrika's challenge: The People's Alliance coalition government loses its parliamentary majority, leaving Sri Lanka poised on the edge of political uncertainty. Frontline, 18(14). [Online] Available: http://www.frontline.in/static/html/ fl1814/18140530.htm (January 1, 2015).

Tamil Guardian. 2014. Government rejects SLMC demand for separate administrative district for Muslims. Tamil Guardian, 4 November. [Online] Available: http://www.tamilguardian.com/article.asp?articleid=12774 (April 24, 2015).

The Island. 2013. Hakeem threatens to quit portfolio in one month if...... cornered by Amparai SLMC voters. The Island, 8 February. [Online] Available: http://www.island.Ik/index.php?page_cat=article-details\&page=article-details\&code title=72202 (January 1, 2015).

Think Worth. 2014. SLMC now a LTTE. [Online] Available: https://thinkworth.wordpress.com/2014/12/30/slmc-now-a-Itte-daily-news-srilankal (April 20, 2016).

Uthayan (News paper). 4-17, December 1981.

Yusoff, M.A \& Sarjoon, A. 2016. On the margin: A critical assessment of Muslims' concerns in the post-war development and settlement process in Sri Lanka. Conference Paper. $8^{\text {th }}$ International Conference on Innovation in Humanities and Social Sciences. National Defense University of Malaysia. Kuala Lumpur. 27-28, May.

Yusoff, M.A., Sarjoon, A \& Hassan, M.A. 2016. An analysis of the development impacts of establishing Kalmunai administrative district in Sri Lanka." Journal of Sustainable Development, 9(1), 164-176. 


\title{
Project-based Learning: "Teens' Magazine"- A Case Study in an English Language Classroom in Albania
}

\author{
Merita Hoxha, PhD Candidate
}

Mentor teacher at "Naim Frashëri" school, University "Aleksandër Xhuvani" Email: hoxha.merita@yahoo.com

\author{
Doi:10.5901/ajis.2016.v5n3p73
}

\section{Abstract}

Over the past 5 years, Project-Based Learning (PBL) has become an integral part of the curriculum in all elementary and high schools in Albania. This might be due to the fact that this is an alternative way of teaching which tries to engage all the students in the learning process despite their level of knowledge in a specific subject. PBL is a method of teaching and learning which puts the students at the center of the learning process and as a result of students having to produce a final result, it considered to be very motivating and satisfactory for them. Scholars think that PBL integrates knowing and doing and is therefore a style of active learning. Generally, it involves real life topics which students have to discuss in groups, research and even generate solutions. This increases the possibility of long-term retention of skills and concepts. In this case study we will see how a mini version of PBL operates. The project "Teens' magazine" was conducted with students of the 7th grade in "Naim Frashëri" school, in Elbasan, Albania. I will give details on how the project took place, the process of creating the groups, assigning the tasks and how it was assessed. Another important part of this case study is describing what worked and what didn't work during the project. Because this project was conducted for three years with 7th graders, this case study will also give information on how parts of the process have changed and improved.

Keywords: project-based learning, student, teacher, group, assessment

\section{Rationale}

During the past 20 years many things have changed in the education system in Albania. As in many other countries, our classes used to be teacher-centered, while based on new pedagogical theory, we are trying to modernize current methodology. Changes are not easy and they happen gradually. Moving from small, isolated projects to PBL is one of the key challenges within our education system. Since 2014, with the reformation of the education system and changes in the curricula, teachers have been asked to focus more on PBL, unfortunately often without proper training or appropriate instruction in how to apply PBL.

\section{Literature Review}

PBL started to be used as an alternative teaching method in the last two decades but it is becoming very popular among teachers, students and schools in many parts of the world. Despite this it is important to emphasize that the roots of PBL date back nearly 100 years ago to the famous American scholar John Dewey, who believed that engaging students in solving real problems during learning will develop their personal investment. The main reason for the growing popularity of PBL is that it is considered to be a student-centered approach which combines knowledge and skills. Some other reasons for using PBL are:

- PBL makes school more engaging for students.

- PBL improves learning

- PBL builds success skills for college, career, and life

- PBL provides opportunities for students to use technology

- PBL makes teaching more enjoyable and rewarding

- PBL connects students and schools with communities and the real world

Because it is a new approach, it is important to understand what is and what is not PBL. Lenz (2016) says that currently, there is no widely agreed-upon definition and detailed description of what high quality PBL looks like in practice. Sometimes "hands-on" learning and "fun" activities are mistaken as PBL, says the author. Even Thom (2011) draws 